\title{
酵母に学ぶマイトファジーの機構と生理機能
}

\author{
福田智行，神吉智丈 \\ 新潟大学大学院医歯学総合研究科機能制御学分野 干951-8510 新潟市中央区旭町通 1-757
}

要旨：ミトコンドリアは酸素呼吸により細胞に必要なエネルギーの大半を作りだすオルガネラである。一方，呼吸の副産 物としてミトコンドリアからは活性酸素が生じ, 細胞成分に障害を与えてしまう。したがって, 健全な細胞活動のために は，ミトコンドリアの量と質が適切にコントロールされている必要がある。オートファジーによるミトコンドリアの選択 的な分解は，真核細胞が余分あるいは異常なミトコンドリアを取り除く手段の 1 つ考えられている. マイトファジーと よばれるこの反応は，ミトコンドリアの一部を二重膜で囲まれたオートファゴソーム内に包みこみ，次いでリソソームあ

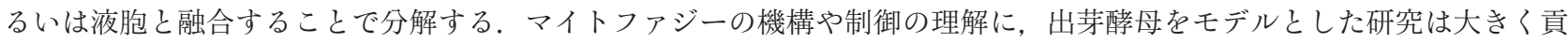
献してきた. 出芽酵母のミトコンドリア外膜に存在するAtg32 はマイトファジーに特異的なレセプターとしてはたらき, オートファジー因子と直接作用することで，分解するミトコンドリアとオートファゴソーム形成の場とを結びつける。ま た，マイトファジーの誘導はAtg32の転写や翻訳後修飾を介して厳密に制御されている。さらに, Atg 32 はマイトファジー に特異的な因子であるため，その欠損株の表現型解析によりマイトファジーの生理的な意義を検証することが可能である. 本稿では, Atg32 を中心に酵母で明らかにされたマイトファジーの機構や制御，意義について紹介する。

\section{Molecular mechanism and physiological functions of mitophagy in yeast}

\section{Tomoyuki Fukuda, Tomotake Kanki}

Department of Cellular Physiology, Niigata University Graduate School of Medical and Dental Sciences, 1-757 Asahimachi-dori, Niigata, 951-8510 Japan

Authors for correspondence: T. Fukuda, tfukuda@med.niigata-u.ac.jp, T. Kanki, kanki@med.niigata-u.ac.jp

\begin{abstract}
Summary: In eukaryotic cells, mitochondria serve as the central source of cellular energy. As a byproduct of energy production, mitochondria also generate reactive oxygen species. Because accumulation of oxidative damage causes diverse pathologies, cells must maintain a proper pool of functional mitochondria in response to energetic demands and various stimuli. Selective removal of mitochondria by autophagy, called mitophagy, is thought to contribute to elimination of excess or dysfunctional mitochondria to maintain mitochondrial homeostasis. Mitophagy is a catabolic process where a part of mitochondria is engulfed into double-membrane vesicles termed autophagosomes, which then fuse with lysosomes/vacuoles, resulting in cargo degradation by lysosomal/vacuolar proteases. Studies using the budding yeast Saccharomyces cerevisiae as a model organism have significantly contributed to the understating of the mechanism, regulation, and functional roles of mitophagy. In S. cerevisiae, Atg32, a mitochondrial surface protein, is a key molecule in mitophagy, serving as a mitophagy receptor that connects a part of mitochondria to the autophagy machinery through its direct interaction with autophagy proteins required for autophagosome formation. Mitophagy induction in yeast is tightly controlled through transcriptional and post-translational regulations of Atg32. Furthermore, physiological functions of mitophagy have been explored using cells deleted for Atg32 as mitophagy-deficient mutants since Atg32 is a mitophagy-specific protein. In this review, by focusing on yeast mitophagy, we overview recent advances in our understanding of the molecular mechanism and physiological functions of autophagic degradation of mitochondria.
\end{abstract}

Key words: Atg32, autophagy, mitochondria, mitophagy, yeast

はじめに

ミトコンドリアは細胞全体の約 $10 〜 20 \%$ を占めるオル ガネラで, 多種の代謝経路, 細胞死, カルシウム恒常性の 維持といつた様々な細胞機能において必須の役割を果たす. 中でもミトコンドリアで生じる酸素呼吸は, 細胞の活動に 必要なエネルギーの大半を産み出す重要な反応である。一 方, 呼吸の副産物としてミトコンドリアからは絶えず活性 酸素が発生してしまう。通常, 活性酸素は抗酸化酵素によ り除去されるため, 酸化還元状態のバランスは維持される が, 疾患や老化, ミトコンドリアの機能低下などによりこ のバランスが崩れると, 細胞に重篤な酸化ストレスが引き 起こされてしまう。そこで, 細胞は機能の低下したミトコ ンドリアや, 余分なミトコンドリアを取り除く必要がある.
マイトファジーとよばれる, 選択的なオートファジーがミ トコンドリアを分解する反応は，ミトコンドリアの量と質 のコントロールを司る経路の 1 つ考えられている。近年, パーキンソン病のようなヒトの神経変性疾患とマイトファ ジー機能不全との関わりが示唆されており, マイトファジー は注目の対象となっている。

マイトファジーはオートファジーの一種であるため, オー トファジーに関わる因子のほとんどがマイトファジーにも はたらく．本来オートファジーは選択制のない異化反応経 路である (図1)。隔離膜とよばれる二重膜の構造が細胞質 で構築され，伸長して細胞質成分をランダムにとり囲み， オートファゴソームとよばれる小胞を形成する。 オートファ ゴソームがリソソームあるいは液胞と融合すると, 加水分 


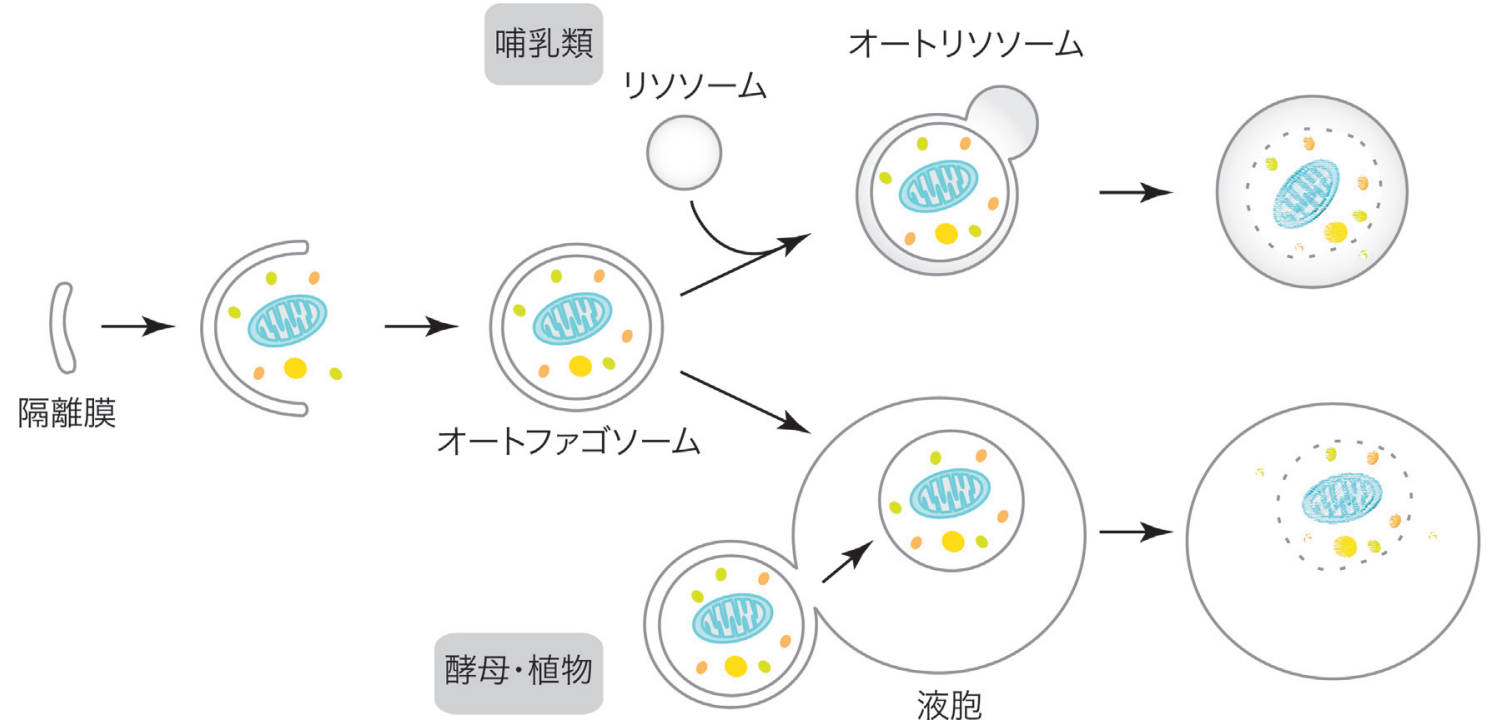

図 1 オートファジーによる細胞質成分の分解. オートファジーの誘導により形成された隔離膜が伸長し，オートファゴソームが構築され る。オートファゴソームはリソソームあるいは液胞と融合することで, 内容物を分解する.

解酵素のはたらきにより内容物が分解される。こうしたオー トファジーの機構は, ノーベル賞を受賞した大隅良典教授 のグループを中心に, 出芽酵母 (Saccharomyces cerevisiae) を モデルとした研究によって進展してきた。をりわけ，オー トファゴソーム形成に関わるAtgタンパク質群の同定と解 析により，オートファジー機構の理解が飛躍的に進んだ. その後, オートファジーの基質の一部は選択的にオートファ ゴソームへ取り込まれることが分かり，ミトコンドリアに 加え, ペルオキシソーム, リボソーム, 小胞体, リソソー ムのようなオルガネラや, タンパク質凝集体, 出芽酵母の 特定の分解酵素 (Ape1, Ams1タンパク質) な゙゙が選択的オー トファジーの基質として同定されている。こうした選択的 オートファジーの機構や制御の理解にも, 酵母を用いた研 究が多大な貢献を果たしている。本稿では出芽酵母のマイ トファジーに焦点を当て, その機序と生理機能について解 説する.

\section{$\operatorname{Atg} 32$ はマイトファジーのレセプターとして機能する}

出芽酵母におけるマイトファジ一研究のブレイクスルー となったのは, マイトファジーを検出する手法の確立と, 遺伝学的探索によるマイトファジー因子の同定だといえる. 初期の出芽酵母のオートファジ一研究では, マイトファジー によって液胞に取り込まれたミトコンドリアが電子顕微鏡 で観察されていた (Takeshige et al. 1992)。その後, GFPな ぞの蛍光タンパク質をミトコンドリアタンパク質に付加し て発現することで, 液胞に運ばれたミトコンドリアタンパ ク質を蛍光顕微鏡観察で検出したり, 液胞でのミトコンド リアタンパク質の分解をウエスタンブロッティングで検出 したりすることが可能になった (Kissova et al. 2004, Kanki and Klionsky 2008). こうした比較的簡便な検出系を用い て様々な遺伝子破壊株のマイトファジーが解析された結 果, オートファジーに必要なAtgタンパク質のほとんどが マイトファジーにも必要であることが見出された。一方で,
Atg11, Atg20, Atg24のような, 非選択的なオートファジー には必須ではないが選択的オートファジーには必要な因子 の遺伝子破壊株がマイトファジ一欠損を示すことから，マ イトファジーは選択的オートファジーであることが遺伝学 的に明らかにされた (Kanki and Klionsky 2008, Kanki et al. 2009, Okamoto et al. 2009).

選択的オートファジーには標的ごとに特異的なレセプ タ一分子が存在し, 選択性の原動力となっている.いずれ も標的の表面に局在して分解の目印となり, オートファジー 因子との相互作用を介して標的とオートファゴソーム形成 の場とを結びつける. Atg32タンパク質は, 出芽酵母の遺 伝子破壊株ライブラリ一を用いた網羅的因子探索によりマ イトファジーに必須の因子として同定され, 詳細な解析か らレセプターとしてはたらくことが示された (Kanki et al. 2009, Okamoto et al. 2009, Kondo-Okamoto et al. 2012). $\operatorname{Atg} 32$ はミトコンドリア外膜に存在する一回膜貫通タンパ ク質で， $\mathrm{N}$ 末端を細胞質に， C末端を膜間腔に露出する. 細胞質にあるAtg32の $\mathrm{N}$ 末端領域はオートファジ一因子 のAtg8 とAtg11に直接結合する(図2)。Atg32 と Atg8の結 合はAtg32の N末端領域に存在するAtg8-family interacting motif (AIM) あるいはLC3-interacting region (LIR) とよば れるコンセンサス配列 (W/F/Y)XX $(\mathrm{L} / \mathrm{I} / \mathrm{V})$ に依存する。 AIMあるいはLIRは選択的オートファジーのレセプター に共通して見られる配列で, レセプターとAtg8あるいは LC3 (Atg8の哺乳類ホモログ) との結合を司る配列である. また, Atg11 との結合に必要な領域に見られる (I/V)LS と いう配列も, 出芽酵母の選択的オートファジーのレセプター 間でよく保存されている. Atg8 はリン脂質のフォスファ チジルエタノールアミンに共有結合するユビキチン様タン パク質で, 隔離膜に局在してオートファゴソームの形成に 重要な役割を果たす。一方, Atg11 はオートファゴソーム 形成に関わる因子群が集合する足場となるタンパク質で, 選択的オートファジーの標的とオートファジータンパク 
質群をつなぐアダプターとして機能する。これら Atg8 や $\operatorname{Atg} 11$ との相互作用を介して, Atg32 はオートファゴソー ム形成に関わる因子群をミトコンドリアに集合させて, 分 解へと導くレセプターとしてはたらく。

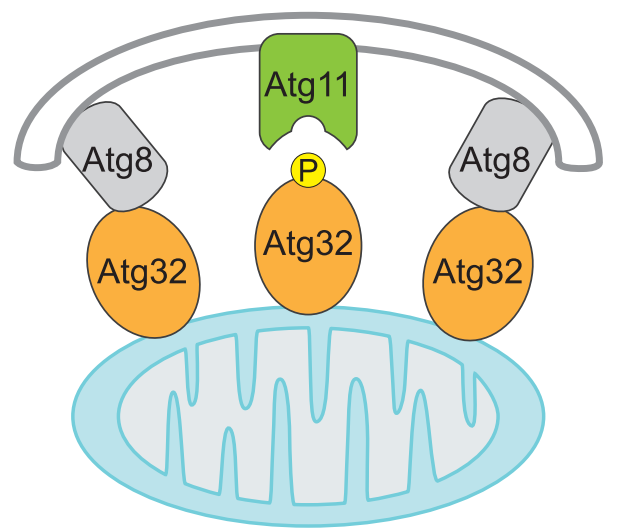

図2 マイトファジーのレセプターとしてはたらくAtg32. ミトコ ンドリア外膜に局在する Atg 32 は分解の目印となり, オートファジー 因子の Atg11 とAtg8 に結合することでオートファゴソーム形成の 場をミトコンドリアにリクルートする.

\section{Atg32を介したマイトファジーの誘導制御}

出芽酵母に効率よくマイトファジーを誘導させるため には，あらかじめグリセロールや乳酸のような非発酵性 の炭素源を含む呼吸培地で培養し，そのまま定常期まで 培養し続けるか，あるいはグルコースを炭素源とする窒 素源欠乏培地に移すことで窒素源飢餓状態にする (Kissova et al. 2004, Kanki and Klionsky 2008). 呼吸培地での培 養はミトコンドリアの量を増加させるとともに, ATG32 遺伝子の転写も誘導する。ATG32遺伝子の転写制御には DNA 結合タンパク質Ume6 とヒストン脱アセチル化酵素 複合体 Sin3-Rpd3 が関与している (Aihara et al. 2014)。こ れらのタンパク質は $A T G 32$ 遺伝子の転写発現を抑制して おり, 飢餓や呼吸培地での生育ではこの抑制が外れるこ とにより ATG32が誘導されると考えられている. Ume6 と $\operatorname{Sin} 3-R p d 3$ は $A T G 8$ 遺伝子の転写制御にも関与することか ら (Bartholomew et al. 2012), Atg32 はオートファジー因子 と共にその発現が制御されているといえる.

マイトファジーを誘導した細胞を抗酸化剂 $\mathrm{N}$-acetylcysteine (NAC) で処理するとマイトファジーが減 少することから，活性酸素がマイトファジーを促進する と考えられてきた. マイトファジーと同様にAtg32の発現 も NAC処理により減少するため (Okamoto et al. 2009), Atg 32 の発現誘導がマイトファジー誘導制御の初発反応か もしれない. NAC処理はグルタチオンの代謝にも影響す るため, Atg32の発現やマイトファジーの誘導は細胞の酸 化還元状態に依存している可能性も指摘されている (Deffieu et al. 2009). 他にも, Atg32の発現はタンパク質 $\mathrm{N}$ 末端ア セチル化酵素 NatAの欠損株でも減少することが見出され ている (Eiyama and Okamoto 2015). NatA はリボソーム と結合し, 新生ポリペプチド鎖の $\mathrm{N}$ 末端のアミノ酸残基に 対して, アセチルCoAからアセチル基を転位させる。そ のため, NatAの基質の中に $A T G 32$ の転写制御に関わる因
子が含まれていると予想されている。また, ATG32の転 写はリン脂質のメチル化の影響を受けることが報告されて いる (Sakakibara et al. 2015)．このリン脂質のメチル化は 還元型グルタチオンの量にも影響することから，細胞の酸 化還元状態に依存して ATG32の発現量を変動させている かもしれない.

転写制御に加え, Atg32 は翻訳後修飾による調節も受ける. 主要な修飾として，マイトファジー誘導時に検出される $\operatorname{Ser}^{114}$ と Ser ${ }^{119}$ 残基におけるリン酸化が見出されている(Aoki et al. 2011). とりわけSer ${ }^{114}$ のリン酸化はマイトファジー およびAtg32とAtg11の結合に必要であり, Atg32 と Atg8 との結合には影響しない (Aoki et al. 2011, Kondo-Okamoto et al. 2012). 出芽酵母のプロテインキナーゼの破壊株を 用いた網羅的なスクリーニングから，カゼインキナーゼ 2 (CK2) が Ser ${ }^{114}$ と Ser ${ }^{119}$ をリン酸化するキナーゼとして同定 されている (Kanki et al. 2013). CK2 の欠損株ではAtg32の リン酸化が減少し, Atg32 と Atg11 の結合やマイトファジー も低下するため, CK2 による Atg32 のリン酸化はマイトファ ジ一を促進するといえる. CK2 は恒常的に発現している ため, マイトファジー誘導条件にのみAtg32のリン酸化を 上昇させる未知の機構が存在していると考えられる.

$\operatorname{Atg} 32$ がリン酸化以外の翻訳後修飾を受けることも知ら れている。ミトコンドリア膜間腔にあるAtg32のC末端 領域は, マイトファジー誘導時にプロセシングを受けて 短くなる (Wang et al. 2013). このプロセシングはミトコ ンドリアのi-AAA (ATPase associated with various cellular activities) プロテアーゼYme1 を必要とする.C末端へのエ ピトープタグの付加あるいはYme1の遺伝子破壊によりこ のプロセシングを阻害すると，マイトファジーは減少する。 また, Yme1の遺伝子破壊株ではAtg32 とAtg11 との相互作 用も低下することから，C末端領域のプロセシングが隔離 膜の形成に影響する可能性が示唆されている。このC末端 でのプロセシングの他にも， ウエスタンブロッティングで 検出されるAtg320分子量を $20 \mathrm{kDa}$ 増大させる非リン酸 化系の修飾も見出されている (Levchenko et al. 2016). こ の修飾は液胞でのタンパク質分解を阻害する際に観察され ることから, 通常は修飾を受けたAtg32 は効率よく分解さ れていると予想される。 さらに，この修飾にはオートファ ジ一因子が必要なことから, 修飾とオートファゴソームの 形成がリンクしている可能性がある。

\section{マイトファジーに影響するAtg32以外の因子}

マイトファジーのレセプターとしてはたらくAtg32の他 にも，マイトファジーに影響する様々な因子や要因が同定 されている. 以下に代表的なものとして，ミトコンドリア と小胞体間の接触と, ミトコンドリア分裂の関与について 紹介する.

近年, 哺乳類細胞においてオートファゴソームは小胞体 とミトコンドリアの接触部位で形成されることが報告さ れている。 マイトファジーのような選択的なオートファ ジーが生じる場についての詳細な解析はないものの, 出 芽酵母においてミトコンドリアと小胞体との接触に必要 なER-mitochondria encounter structure (ERMES) 複合体が マイトファジーに関与することが見出されている (Bockler and Westermann 2014). ERMESの欠損株ではマイトファ 
ジーが減少するものの，この欠損株で人為的にミトコンド リアと小胞体を接触させるとマイトファジーが回復するこ とから, ERMES自体ではなくミトコンドリアと小胞体の 接触がマイトファジーに重要な役割を果たしているといえ る. ERMES はマイトファジー誘導時にAtg32やオートファ ジ一因子と共局在し， ERMESが欠損するとオートファゴ ソーム形成が完了しない.したがって, 隔離膜が伸長して ミトコンドリアを包む際に, ERMES はオートファゴソー 厶形成の場を小胞体に近接させることで, 小胞体から膜 の伸長に十分な量の脂質が供給されるようにしているか もしれない。 また, ERMESの構成因子の一部 (Mdm34 と Mdm12) のユビキチン化がマイトファジーを促進すること も報告されている (Belgareh-Touze et al. 2017).

ミトコンドリアは分裂と融合により, その形態やサイズ を調整する。 ミトコンドリアのサイズはオートファゴソー ムに比べてはるかに大きいため，隔離膜で包みこむために はミトコンドリアを分裂させて小さな断片を作り出すこと が必要だと長らく考えられてきた。実際に，酵母のミトコ ンドリア分裂に関わるダイナミン様タンパク質 Dnm1 は, $\operatorname{Atg} 11$ と結合することでミトコンドリア上のオートファゴ ソーム形成の場にリクルートされる (Mao et al. 2013).

方で, Dnm1の欠損株でも相当な量のマイトファジーが認 められることから, Dnm1に依存しない形でミトコンドリ アが分裂して断片化するが生じる可能性が示唆されてき た. 同様に, 哺乳類細胞では分裂因子 Drp1 (Dnm1 の哺乳 類ホモログ) を欠損しても，マイトファジーは正常に生じ る (Yamashita et al. 2016)。 また, 哺乳類細胞にマイトファ ジーを誘導すると，オートファゴソーム形成の場において Drp1に依存せずにミトコンドリアの一部が断片化して隔 離膜に包まれる様子が観察されている。こうした既知の分 裂因子に依らないミトコンドリア断片化の機序については, 今後の研究の発展に興味がもたれる.

\section{マイトファジーの生理的意義}

哺乳類では, マイトファジーが多様な生理機能を果た すことが知られている。例えば, 赤血球の発生段階にお けるミトコンドリアの除去はマイトファジーを必要とす る (Schweers et al. 2007, Sandoval et al. 2008). また, 寒冷 刺激に応じて白色脂肪細胞はミトコンドリアを多く含む ベージュ細胞へと分化して熱産性能を上昇させるが, 刺 激がなくなり白色脂肪細胞に戻る際にはマイトファジー によってミトコンドリアを減少させる (Altshuler-Keylin et al. 2016). さらに, 若年性パーキンソン病の原因遺伝子で あるPARK2 とPINK1/PARK6がそれぞれコードするタン パク質Parkin とPINK1が, 脱分極した異常なミトコンド リアの除去を担う因子であることが明らかになっている (Narendra et al. 2008, Narendra et al. 2010)。こうした一過 的に誘導されるマイトファジーに加えて，様々な組織で恒 常的にマイトファジーが生じていることが観察されている (McWilliams et al. 2018).

酵母細胞においても, マイトファジーは機能低下したミ トコンドリアの除去により, ミトコンドリアの品質維持に 貢献すると考えられている，哺乳類細胞とは異なり，酵母 の場合, 脱共役剂やミトコンドリアATP合成酵素の阻害 剤でミトコンドリア機能を阻害してもマイトファジーの顕
著な誘導は見られない。しかし, ミトコンドリアATP合 成酵素のフォールディングや内膜でのイオン交換を欠損さ せることでミトコンドリアの機能を低下させた際に, マイ トファジーが誘導されることが見出されている (Priault et al. 2005, Nowikovsky et al. 2007). 出芽酵母のマイトファ ジーは, 酸素呼吸培地での長期培養や窒素源飢餓により効 率よく誘導される. オートファジーの欠損株をこうした 条件におくと, 細胞内に活性酸素が蓄積すると同時に機 能低下したミトコンドリアが増加してしまう (Zhang et al. 2007). また, Atg32やAtg11のようなマイトファジー因子 を欠損した出芽酵母では, 活性酸素あるいは酸化ストレス に起因してミトコンドリアゲノムの不安定性が上昇するた め, 呼吸能を失ったミトコンドリアをもつ細胞が増加する (Kurihara et al. 2012). 分裂酵母 Schizosaccharomyces pombeに おいても, 窒素源飢餓時にプロテアソームの機能が低下す るとミトコンドリアで過剩な活性酸素が生じるため, マイ トファジーによるミトコンドリアの除去が細胞の生存に必 要となる (Takeda et al. 2010). 現在までのところ, 酵母の マイトファジーが機能の低下したミトコンドリアを特異的 に認識して除去するのか, それともミトコンドリア全体の 量支減らすことで活性酸素の蓄積支抑えているのかについ ての明確な理解は得られていない, ただ, プロテオミクス 解析により, マイトファジーによるマトリックスのタンパ ク質の分解速度はタンパク質ごとに異なることが報告され ており (Abeliovich et al. 2013), 特定のタンパク質群ある いはミトコンドリア領域が優先して分解される可能性があ る.

マイトファジーがミトコンドリアDNAの品質管理に寄 与する可能性も示唆されている. 通常, 酵母細胞のミト コンドリアDNA は同一のコピーで占められたホモプラス ミーとよばれる状態になっている。一方, 活性酸素などの 影響から生じた突然変異を含む変異型のコピーが混在する 状態をへテロプラスミーとよぶ. 中でも大きな欠失を含む 変異型のミトコンドリアDNAは, 呼吸能はないもののゲ ノムサイズが小さく短時間で複製されるためにコピー数が 増加し易く, 世代を経るとポピュレーションの大半を占め るようになる。こうした大きな欠失を含むミトコンドリア DNA をもつ酵母と, 通常型のミトコンドリアDNAをもつ 酵母が接合すると, その接合子においてマイトファジーが 誘導され, マイトファジーに依存して変異型のミトコンド リアDNAのコピーの増加が抑えられることが見出されて いる (Karavaeva et al. 2017). 呼吸能を無くした变異型のミ トコンドリアDNAが何らかの機構で選択され, マイトファ ジーによって除去されるのかもしれない. ヘテロプラスミー における変異型ミトコンドリアDNAの増減はミトコンド リア病発症の主要因であるため, 今後の研究展開に興味が もたれる。

応用面からも, マイトファジーに着目した研究が行わ れている. カンジダ酵母 Candida glabrata は免疫不全患者 に日和見感染を引き起こす。宿主体内ではトランスフェ リンやフェリチンのような鉄結合タンパク質が存在し, C. glabrataにとつては鉄欠乏環境となる. 鉄欠乏時の $C$. glabrataではマイトファジーが活性化しており, Atg32の遺 伝子破壊によってマイトファジーが久損すると長期間生存 できない(Nagi et al. 2016). また，マウスを用いた実験に 
よりAtg32 を欠損したC. glabrataの病原性が低下すること も示されている。したがって，マイトファジ一関連因子が 抗真菌薬の標的になるかもしれない。一方, 発酵生産にお けるマイトファジーの機能も解析されている。醸造中の酵 母ではマイトファジーが誘導されており, Atg 32 の遺伝子 破壊によってマイトファジーが欠損すると発酵能が高まる ことが報告されている (Shiroma et al. 2014).

\section{おわりに}

真核生物において，マイトファジーはミトコンドリアの 量や質をコントロールすることにより多様な生理機能を果 たす。マイトファジーのレセプターとして Atg32が同定さ れて以来, 出芽酵母におけるマイトファジーの分子機構や 生理的役割の理解が進んできた。一方で, 例えばマイトファ ジーの誘導機構については，マイトファジーを活性化する 刺激や，刺激を Atg32の発現誘導や修飾に伝えるシグナル 伝達経路，過剩なマイトファジーを抑制するための負の制 御の有無なぞ, 今後明らかにされるべき課題も多く残され ている。 また，ミトコンドリアの特定の領域が認識されて 優先的に分解されているか否か, 分解に特異性があるので あればその機構についても今後の解析が求められる。さら に，ミトコンドリアがオートファゴソームに包まれる機構 に関しても，オートファジ一因子の集合や，膜形成のため の脂質の供給, 既知のミトコンドリア分裂因子に依存しな いミトコンドリアの断片化，といった個々のステップに関 する分子レベルでの詳細な研究が重要である。 マイトファ ジー以外の選択的オートファジーや非選択的オートファジー の研究も精力的に行われているため, 多種のオートファジー 研究の進展により, 双方向的に理解の深化が促されると期 待できる。

本稿では出芽酵母の知見に焦点を絞つたが，哺乳類細胞 におけるマイトファジー研究も, Parkin やPINK1の関与 が明らかになって以来著しく発展している。また, Parkin やPINK1 存含む経路の他にも, Atg32 と同様に外膜に存在 するレセプターによって誘導されるマイトファジーが複数 同定されている。こうした多様な経路によるマイトファジー 誘導の機構が明らかになり始めた一方で，パーキンソン病 そマイトファジー欠損との直接的な因果関係は今のところ 見出されていない. 今後, 哺乳類細胞に打りマイトファ ジ一制御の機構解明に, 酵母のマイトファジーの機構や, Atg32 介した制御の知見が貢献するかもしれない.

最後に，オートファジーは真核生物間で高度に保存され ているものの, 植物細胞におけるマイトファジーはほとん ぞ明らかになっていない.しかし，オートファジーによる 小胞体やペルオキシソームの分解に加えて, オートファ ジーで葉緑体を分解する経路が同定されている (Izumi and Nakamura 2017). 今後, 多様な生物種において, ミトコン ドリアに限らず, 様々なオルガネラやその他の基質を認識 して分解するオートファジーの分子機序, 制御機構, 生理 機能の研究により，真核生物間におけるオートファジーの 普遍性や多様性が明らかになってゆくと期待される。

\section{引用文献}

Abeliovich, H., Zarei, M., Rigbolt, K. T., Youle, R. J., and

Dengjel, J. (2013) Involvement of mitochondrial dynamics in the segregation of mitochondrial matrix proteins during stationary phase mitophagy. Nat Commun 4: 2789.

Aihara, M., Jin, X., Kurihara, Y., Yoshida, Y., Matsushima, Y., Oku, M., Hirota, Y., Saigusa, T., Aoki, Y., Uchiumi, T., Yamamoto, T., Sakai, Y., Kang, D., and Kanki, T. (2014) Tor and the Sin3-Rpd3 complex regulate expression of the mitophagy receptor protein Atg32 in yeast. J Cell Sci 127: 3184-3196.

Altshuler-Keylin, S., Shinoda, K., Hasegawa, Y., Ikeda, K., Hong, H., Kang, Q., Yang, Y., Perera, R. M., Debnath, J., and Kajimura, S. (2016) Beige adipocyte maintenance is regulated by autophagy-induced mitochondrial clearance. Cell Metab 24: 402-419.

Aoki, Y., Kanki, T., Hirota, Y., Kurihara, Y., Saigusa, T., Uchiumi, T., and Kang, D. (2011) Phosphorylation of Serine 114 on Atg32 mediates mitophagy. Mol Biol Cell 22: 32063217.

Bartholomew, C. R., Suzuki, T., Du, Z., Backues, S. K., Jin, M., Lynch-Day, M. A., Umekawa, M., Kamath, A., Zhao, M., Xie, Z., Inoki, K., and Klionsky, D. J. (2012) Ume6 transcription factor is part of a signaling cascade that regulates autophagy. Proc Natl Acad Sci USA 109: 1120611210.

Belgareh-Touze, N., Cavellini, L., and Cohen, M. M. (2017) Ubiquitination of ERMES components by the E3 ligase Rsp5 is involved in mitophagy. Autophagy 13: 114-132.

Bockler, S. and Westermann, B. (2014) Mitochondrial ER contacts are crucial for mitophagy in yeast. Dev Cell 28: 450-458.

Deffieu, M., Bhatia-Kissova, I., Salin, B., Galinier, A., Manon, S., and Camougrand, N. (2009) Glutathione participates in the regulation of mitophagy in yeast. J Biol Chem 284: 1482814837.

Eiyama, A. and Okamoto, K. (2015) Protein N-terminal Acetylation by the NatA Complex Is Critical for Selective Mitochondrial Degradation. J Biol Chem 290: 25034-25044.

Izumi, M. and Nakamura, S. (2017) Partial or entire: Distinct responses of two types of chloroplast autophagy. Plant Signal Behav 12: e1393137.

Kanki, T. and Klionsky, D. J. (2008) Mitophagy in yeast occurs through a selective mechanism. $J$ Biol Chem 283: 3238632393.

Kanki, T., Kurihara, Y., Jin, X., Goda, T., Ono, Y., Aihara, M., Hirota, Y., Saigusa, T., Aoki, Y., Uchiumi, T., and Kang, D. (2013) Casein kinase 2 is essential for mitophagy. EMBO Rep 14: 788-794.

Kanki, T., Wang, K., Cao, Y., Baba, M., and Klionsky, D. J. (2009) Atg32 is a mitochondrial protein that confers selectivity during mitophagy. Dev Cell 17: 98-109.

Karavaeva, I. E., Golyshev, S. A., Smirnova, E. A., Sokolov, S. S., Severin, F. F., and Knorre, D. A. (2017) Mitochondrial depolarization in yeast zygotes inhibits clonal expansion of selfish mtDNA. J Cell Sci 130: 1274-1284.

Kissova, I., Deffieu, M., Manon, S., and Camougrand, N. (2004) Uth1p is involved in the autophagic degradation of 
mitochondria. J Biol Chem 279: 39068-39074.

Kondo-Okamoto, N., Noda, N. N., Suzuki, S. W., Nakatogawa, H., Takahashi, I., Matsunami, M., Hashimoto, A., Inagaki, F., Ohsumi, Y., and Okamoto, K. (2012) Autophagy-related protein 32 acts as autophagic degron and directly initiates mitophagy. J Biol Chem 287: 10631-10638.

Kurihara, Y., Kanki, T., Aoki, Y., Hirota, Y., Saigusa, T., Uchiumi, T., and Kang, D. (2012) Mitophagy plays an essential role in reducing mitochondrial production of reactive oxygen species and mutation of mitochondrial DNA by maintaining mitochondrial quantity and quality in yeast. J Biol Chem 287: 3265-3272.

Levchenko, M., Lorenzi, I., and Dudek, J. (2016) The Degradation Pathway of the Mitophagy Receptor Atg32 is re-routed by a posttranslational modification. PLOS One 11: e0168518.

Mao, K., Wang, K., Liu, X., and Klionsky, D. J. (2013) The scaffold protein Atg11 recruits fission machinery to drive selective mitochondria degradation by autophagy. Dev Cell 26: 9-18.

McWilliams, T. G., Prescott, A. R., Montava-Garriga, L., Ball, G., Singh, F., Barini, E., Muqit, M. M. K., Brooks, S. P., and Ganley, I. G. (2018) Basal Mitophagy Occurs Independently of PINK1 in Mouse Tissues of High Metabolic Demand. Cell Metab 27: 439-449 e435.

Nagi, M., Tanabe, K., Nakayama, H., Ueno, K., Yamagoe, S., Umeyama, T., Ohno, H., and Miyazaki, Y. (2016) Irondepletion promotes mitophagy to maintain mitochondrial integrity in pathogenic yeast Candida glabrata. Autophagy 12: $1259-1271$.

Narendra, D., Tanaka, A., Suen, D. F., and Youle, R. J. (2008) Parkin is recruited selectively to impaired mitochondria and promotes their autophagy. J Cell Biol 183: 795-803.

Narendra, D. P., Jin, S. M., Tanaka, A., Suen, D. F., Gautier, C. A., Shen, J., Cookson, M. R., and Youle, R. J. (2010) PINK1 is selectively stabilized on impaired mitochondria to activate Parkin. PLOS Biol 8: e1000298.

Nowikovsky, K., Reipert, S., Devenish, R. J., and Schweyen, R. J. (2007) Mdm38 protein depletion causes loss of mitochondrial $\mathrm{K}+/ \mathrm{H}+$ exchange activity, osmotic swelling and mitophagy. Cell Death Differ 14: 1647-1656.

Okamoto, K., Kondo-Okamoto, N., and Ohsumi, Y. (2009) Mitochondria-anchored receptor Atg32 mediates degradation of mitochondria via selective autophagy. Dev Cell 17: 87-97.

Priault, M., Salin, B., Schaeffer, J., Vallette, F. M., di Rago, J. P., and Martinou, J. C. (2005) Impairing the bioenergetic status and the biogenesis of mitochondria triggers mitophagy in yeast. Cell Death Differ 12: 1613-1621.

Sakakibara, K., Eiyama, A., Suzuki, S. W., Sakoh-Nakatogawa, M., Okumura, N., Tani, M., Hashimoto, A., Nagumo, S., Kondo-Okamoto, N., Kondo-Kakuta, C., Asai, E., Kirisako, H., Nakatogawa, H., Kuge, O., Takao, T., Ohsumi, Y., and Okamoto, K. (2015) Phospholipid methylation controls Atg32-mediated mitophagy and Atg8 recycling. EMBO J 34: 2703-2719.
Sandoval, H., Thiagarajan, P., Dasgupta, S. K., Schumacher, A., Prchal, J. T., Chen, M., and Wang, J. (2008) Essential role for Nix in autophagic maturation of erythroid cells. Nature 454: 232-235.

Schweers, R. L., Zhang, J., Randall, M. S., Loyd, M. R., Li, W., Dorsey, F. C., Kundu, M., Opferman, J. T., Cleveland, J. L., Miller, J. L., and Ney, P. A. (2007) NIX is required for programmed mitochondrial clearance during reticulocyte maturation. Proc Natl Acad Sci USA 104: 19500-19505.

Shiroma, S., Jayakody, L. N., Horie, K., Okamoto, K., and Kitagaki, H. (2014) Enhancement of ethanol fermentation in Saccharomyces cerevisiae sake yeast by disrupting mitophagy function. Appl Environ Microbiol 80: 1002-1012.

Takeda, K., Yoshida, T., Kikuchi, S., Nagao, K., Kokubu, A., Pluskal, T., Villar-Briones, A., Nakamura, T., and Yanagida, M. (2010) Synergistic roles of the proteasome and autophagy for mitochondrial maintenance and chronological lifespan in fission yeast. Proc Natl Acad Sci USA 107: 3540-3545.

Takeshige, K., Baba, M., Tsuboi, S., Noda, T., and Ohsumi, Y. (1992) Autophagy in yeast demonstrated with proteinasedeficient mutants and conditions for its induction. J Cell Biol 119: 301-311.

Wang, K., Jin, M., Liu, X., and Klionsky, D. J. (2013) Proteolytic processing of Atg32 by the mitochondrial i-AAA protease Yme1 regulates mitophagy. Autophagy 9: 1828-1836.

Yamashita, S. I., Jin, X., Furukawa, K., Hamasaki, M., Nezu, A., Otera, H., Saigusa, T., Yoshimori, T., Sakai, Y., Mihara, K., and Kanki, T. (2016) Mitochondrial division occurs concurrently with autophagosome formation but independently of Drp1 during mitophagy. J Cell Biol 215: 649-665.

Zhang, Y., Qi, H., Taylor, R., Xu, W., Liu, L. F., and Jin, S. (2007) The role of autophagy in mitochondria maintenance: characterization of mitochondrial functions in autophagydeficient S. cerevisiae strains. Autophagy 3: 337-346.

Received: 14 March 2018 / Accepted: 2 April 2018 